\title{
Efficacies of Some Botanicals Against Covered Kernel Smut [Sphacelotheca Sorghi (Link) Clinton] of Sorghum [Sorghum Bicolor (L.) Moench] at Sheraro, Northwestern Tigray, Northern Ethiopia
}

\author{
Desalegn Yalew ${ }^{1 *}$, Mashilla Dejene ${ }^{2}$, Girma Tegegne ${ }^{3}$ \\ ${ }^{*}$ Ethiopian Institute of Agricultural Research, Fogera National Rice Research and Training Center, P.O. Box: \\ 1937, Bahir Dar, Ethiopia \\ ${ }^{2}$ Haramaya University School of Plant Sciences, P.O. Box: 138 Dire Dawa, Ethiopia \\ ${ }^{3}$ Melkassa Agricultural Research Center, P.O. Box: 436, Adama, Ethiopia
}

*Corresponding Author: Desalegn Yalew, Ethiopian Institute of Agricultural Research, Fogera National Rice Research and Training Center, P.O. Box: 1937, Bahir Dar, Ethiopia

\begin{abstract}
The experiment was conducted at Sheraro Experimental Station of Shire-Maitsebri Agricultural Research Center during 2016 main cropping season, with the objective to investigate the efficacies of some botanicals against covered kernel smut (Sphacelotheca sorghi)of sorghum (Sorghum bicolor). The experiment consisted of six botanicals (Eucalyptus, feto, garlic, ginger, neem, papaya), fermented cow-urine,pure water, all at the rate of $20 \mathrm{ml}$ per $200 \mathrm{~g}$ seed for 30 minutes, and one fungicide (Apron star) at the rate of $10 \mathrm{~g}$ per 4 $\mathrm{kg}$ seed, and untreated or control check. The treatments were arranged in a randomized complete block design (RCBD) with three replications. The analysis of variance showed that there was significant $(p \leq 0.05)$ difference among theseed treatments against the disease. Apron star, cow-urine, neem and papaya leaf crude extracts effectively suppressed the disease as compared to the other treatments. There was no covered kernel smut infection on the plots sown with seeds treated with Apron star, while the highest (30.30\%) incidence and severity (69.14\%) were recorded from plots sown with untreated seeds. Due to this, no yield loss was recorded from plots sown with seeds treated with Apron star, while the highest (48.56\%) yield loss percentage was recorded from plots sown with untreated seeds. Apron star, cow-urine, neem and papaya leaf crude extracts were also more effective and economically feasiblethan other seed treatments.Therefore, farmers can use these effective management methods for sustainable sorghum production in the study area and similar agro-ecologies.
\end{abstract}

Keywords: Botanicals, covered kernel smut, fungicide Apron star, incidence, severity, sorghum bicolor, Sphacelotheca sorghi.

\section{INTRODUCTION}

Sorghum [Sorghum bicolor (L.) Moench] is grown worldwide for food, beverage, fodder and/or fuel, animal feed and cultivated by small-scale farmers at subsistence level and supports the livelihoods of millions of people across the globe, particularly in parts of Africa and Asia (Wortsman et al., 2009; AATF, 2011; Hassan et al., 2015).

Sorghum is one of the most important cereal crops in many developing countries, including Ethiopia. In Ethiopia, it is the third cereal crop in area coverage and volume of production next to tef (Eragrostistef) and maize (Zea mays) (CSA, 2015). The crop is grown over a wide altitudinal range of ecological habitats in the country, growing in between 400-3000meter above sea level(m.a.s.l.)(Awegechew et al., 2015). Out of the total grain crops' area and total grain production, sorghum covers $14.58 \%(1,831,600.45$ hectares) and $16.05 \%(4,339,134.261$ tons), respectively (CSA, 2015).

Sorghum crop has a cultural, social and economic importance in Ethiopia. The grains are used for traditional human consumption and local beverages, such as "Injera", "Nifro", "Tella" and "Arekie". Importantly, its different crop parts are used for different purposes: the leaves provide fodder for farm animals, the stalks for fencing, roofing, weaving baskets and mats, and also as fuel wood (Obilana, 1995). 
However, the yield of sorghum is hindered by many abiotic and biotic factors, including weeds, insect pests, foliar and head or panicle diseases, most predominantly smuts. Among the four major sorghum smuts, covered kernel smut [Sphacelotheca sorghi (Link) Clinton] (syn. Sporisoriumsorghi), is the most common seedborne disease of sorghum where untreated seed is sown, in areas like Sheraro, northwestern Tigray in northern Ethiopia. Field survey resultsin the northwest, northeast, southwest, eastern Ethiopia and Tigray region in sorghum-growing areas indicated that covered kernel smut is one of the major sorghum diseases in the country (Girma et al., 2008).In similar studies, Teklay and Muruts (2015) also reported that the two smut types (namely covered and loose smuts) together showed a prevalence of $37 \%$ with incidence ranging from $0-5 \%$ and severity of $20-100 \%$ in the southern Tigray Region. The traditional farmers' practices using unclean and chemically-untreated seeds are largely responsible for the continued occurrence of sorghum smuts in the region.

To manage covered kernel smut, various promising alternative options have been identified and recommended. Treating seeds with cow or goat urine, chemicals and some botanicals had shown profound effects (Girma et al., 2007; Girma et al., 2008; Aschalew et.la., 2012; Samuel et al., 2014), but none of them were adopted widely to bring an impact on the management of the disease. Probably either farmers lack pertinent information or extension service may not have addressed farmers' need properly.

Nevertheless, none of the abovementioned management options do exist to tackle covered kernel smut problem in Sheraro, northwestern Tigray, northern Ethiopia. Notably, farmers commonly use all available varieties without any seed treatment, which consequently leads to significant or remarkable yield reduction. All these factors combined together affect sorghum yield and subsequently allow the causative agent of covered kernel smut to cycle in the region as a seedborne pathogen. Therefore, this study was directed to test and identify botanical plants that have significant effect to manage covered kernel smut.

Botanical is a bio-pesticide prepared from the parts of plants (leaves, barks, roots, flowers, and seeds). The practice of using plant derivatives or botanicals either in the pure forms or crude extracts to treat against many plant diseases in agriculture dates back many years ago.Misra (2014) reported that till date, about 2400 plant species have been identified to possess pesticidal properties. These botanicals have long been used as attractive alternatives to synthetic chemicals for pest management because botanicals do not pose threat to the environment or to human and animal health. In addition to their safety, the easily availability of botanicals to resource-poor farmers attracts the attention of farmers. Therefore, the antifungal action of plant extracts has gained much attention (Swami and Alane, 2013), and the plants serve as eco-friendly and economic biocontrol agents against many plant pathogenic fungi, including sorghum covered kernel smut pathogen.

Botanicals or plants extracts are promising as alternative or complementary disease management means because of their anti-microbial activity, non-phytotoxicity, systemicity as well as biodegradability. These plants produce a great deal of secondary metabolites, many of them with antifungal activities. Well known examples of these compounds include flavonoids, phenols and phenolic glycosides, unsaturated lactones, sulphur compounds, saponins, cyanogenic glycosides and glucosinolates (Dissanayake and Jayasinghe, 2013). These metabolites are used to protect plants from herbivory effects, and plant pathogens (bacteria, fungi,nematodes and viruses) by killing or inactivating the respective pathogens (Salehan et al., 2013).

As the use of synthetic seed treatment chemicals is beyond the reach of the majority of subsistence farmers in Ethiopia, farmers are looking for other locally available management options (Grima et al., 2007; Aschalew et al., 2012). It is gratuitous that the locally available materials also showed appreciable antifungal activities. In this regard, a significant amount of information has been published (Girma et al., 2007; Girma et al., 2008; Aschalew et al., 2012; Swami and Alane, 2013; Samuel et al., 2014), but there is apparently no significant practical application is made at this time in Tigray region in particular and in Ethiopia in general. However, considering human and environmental safety and readily availability,this untapped approach has a great prospect and potential in organic agriculture for resource-poor farmers in Ethiopia and elsewhere (Varma and Dubey, 1999; Aschalew et al., 2012; Samuel et al., 2014).

Therefore, the current study was carried out in Sheraro, northern Tigray, with the specific objective to investigate the efficacies of some botanicals against covered kernel smut caused by Sphacelotheca sorghi. 
Efficacies of Some Botanicals Against Covered Kernel Smut [Sphacelotheca Sorghi (Link) Clinton] of Sorghum [Sorghum Bicolor (L.) Moench] at Sheraro, Northwestern Tigray, Northern Ethiopia

\section{MATERiAls AND MeTHOdS}

\subsection{Description of the Study Area}

The experiment was conducted atSheraro Experimental Station of Shire-Maitsebri Agricultural Research Center, Northwestern Tigray, during 2016 main cropping season. The study area is located along the main road of Shire to Humera at an altitude of 1028 m.a.s.l., with longitude of $37^{\circ} 45^{\prime} \mathrm{E}$ and latitude of $14^{\circ} 24^{\prime} \mathrm{N}$. The agro-ecology of the area is kolla (lowland agro-ecological zone) with altitude below 1500 m.a.s.l. with annual temperature ranging between 19.3 and $34.8{ }^{\circ} \mathrm{C}$, and an average annual rainfall of $685.2 \mathrm{~mm}$ (Tigray Meteorological Agency, 2016). The soil type of the study site is clayloam. The agricultural activity in Sheraro is mainly rainfall dependent, in which the main rainy season is from mid-June to September.

\subsection{Treatments and Experimental Materials}

In this experiment, six selected botanicals, including Eucalyptus (Eucalyptus globules), feto/garden cress (Lepidiumsativum), garlic (Allium sativum), ginger (Zingiberofficinale), neem (Azadirachtaindica), andpapaya (Carica papaya) were used. In addition to the botanicals, seven days fermented cow-urine, water, one standard check fungicide (Apron star) and an untreatedcheck were included to treat the smut spore-inoculated sorghum variety Gubye seeds. The description of the botanicals that were used for the treatment is given hereunder (Table 1).

Table1. General descriptions of botanicals used for seed treatment against Sphacelotheca sorghi at Sheraro Experimental Station in 2016 main cropping season

\begin{tabular}{|c|c|c|c|c|c|c|}
\hline S.No. & $\begin{array}{c}\text { Common } \\
\text { name }\end{array}$ & Scientific name & $\begin{array}{c}\text { Plant parts } \\
\text { used }\end{array}$ & Formulation & $\begin{array}{c}\text { Application } \\
\text { rate }\end{array}$ & $\begin{array}{c}\text { Reference } \\
\text { S }\end{array}$ \\
\hline 1 & Eucalyptus & $\begin{array}{l}\text { Eucalyptus } \\
\text { globules }\end{array}$ & Leaves & \multirow[t]{6}{*}{$\begin{array}{l}\text { Aqueous } \\
\text { extracts }\end{array}$} & \multirow[t]{6}{*}{$\begin{array}{c}20 \mathrm{ml} / 200 \mathrm{~g} \\
\text { seed }\end{array}$} & \multirow{6}{*}{$\begin{array}{l}\text { Samuel et } \\
\text { al. (2014) } \\
\text { and } \\
\text { Aschalew } \\
\text { et } \\
\text { al.(2012) }\end{array}$} \\
\hline 2 & $\begin{array}{c}\text { Feto } \\
\text { (Garden cress) }\end{array}$ & Lepidiumsativum & Seeds & & & \\
\hline 3 & Garlic & Allium sativum & Bulbs/Cloves & & & \\
\hline 4 & Ginger & Zingiberofficinale & Rhizome & & & \\
\hline 5 & Neem & Azadirachtaindica & Leaves & & & \\
\hline 6. & Papaya & Carica papaya & Leaves & & & \\
\hline
\end{tabular}

\subsection{Treatment Arrangements and Experimental Design}

A total area of $432 \mathrm{~m}^{2}$ was used for the experiment. The plot size was $2.25 \mathrm{~m} \mathrm{x} 5 \mathrm{~m}=11.25 \mathrm{~m}^{2}$ that contained three rows per plot. Each treatment was sown after three rows of the other treatment with a constant spacing of $0.75 \mathrm{~m}$ between rows within a treatment and among treatments. The spacing between replications, rows and plants was $1.5,0.75$ and $0.15 \mathrm{~m}$, respectively, which is a common practice in Shire-Maitsebri Agricultural Research Center. There was a single row of Gubye sorghum variety at the beginning and at the end of each replication as an extra border row. The ten treatment combinations (Table 2) were arranged in a randomized complete block design (RCBD) with three replications. All agronomic practices were applied equally for all plots according to their recommended rates and their appropriate time.

Table2. Treatment descriptions of efficacy trial experiment with botanicals, and cow-urine, water, Apron star and untreated seed as check

\begin{tabular}{|c|c|c|c|c|c|}
\hline \multirow[b]{2}{*}{ S.No. } & \multicolumn{3}{|c|}{ Treatment combinations } & \multirow[b]{2}{*}{ Rate of application } & \multirow[b]{2}{*}{ References } \\
\hline & $\begin{array}{c}\text { Sorghum } \\
\text { variety }\end{array}$ & $\begin{array}{l}\text { Inoculum/ } \\
\text { Pathogen }\end{array}$ & Seed treatment botanicals & & \\
\hline 1 & \multirow{10}{*}{ Gubye } & \multirow{10}{*}{$\begin{array}{c}\text { Sphacelotheca } \\
\text { sorghi }\end{array}$} & $\begin{array}{l}\text { Aqueous extract of } \\
\text { Eucalyptus globules }\end{array}$ & $20 \mathrm{ml} / 200 \mathrm{~g} \mathrm{seed}$ & \multirow{7}{*}{$\begin{array}{l}\text { Samuel et al. } \\
\text { (2014) and } \\
\text { Aschalew et } \\
\text { al.(2012) }\end{array}$} \\
\hline 2 & & & Aqueous extract of feto & $20 \mathrm{ml} / 200 \mathrm{~g}$ seed & \\
\hline 3 & & & Aqueous extract of garlic & $20 \mathrm{ml} / 200 \mathrm{~g} \mathrm{seed}$ & \\
\hline 4 & & & Aqueous extract of ginger & $20 \mathrm{ml} / 200 \mathrm{~g}$ seed & \\
\hline 5 & & & Aqueous extract of neem & $20 \mathrm{ml} / 200 \mathrm{~g}$ seed & \\
\hline 6 & & & Aqueous extract of papaya & $20 \mathrm{ml} / 200 \mathrm{~g}$ seed & \\
\hline 7 & & & Cow urine & $20 \mathrm{ml} / 200 \mathrm{~g}$ seed & \\
\hline 8 & & & Pure water & --- & --- \\
\hline 9 & & & Apron star & $10 \mathrm{~g} / 4 \mathrm{~kg}$ seed & $\begin{array}{c}\text { Samuel et al. } \\
\text { (2014) }\end{array}$ \\
\hline 10 & & & Untreated/control check & --- & --- \\
\hline
\end{tabular}

International Journal of Research Studies in Agricultural Sciences (IJRSAS)

Page $\mid 13$ 


\subsection{Experimental Procedures}

\subsubsection{Seed Inoculation}

Seeds of the Gubye sorghum variety were obtained from Shire-Maitsebri Agricultural Research Center. These seeds were surface-disinfected by soaking with $10 \%$ Chlorox (sodium hypochlorite, $\mathrm{NaOCl}$ ) and rinsed three times with sterilized distilled water before inoculation to ensure freedomfrom any contaminant. Then these seeds were artificially inoculated with teliospores of Sphacelothecasorghi, collected from the previous cropping season. The inoculation rate was $2 \mathrm{~g}$ spore per kg sorghum seed (Merkuz and Getachew, 2012). To inoculate uniformly, the spores and seeds were thoroughly shaken in a paper bag. To ensure infection, the inoculated seeds were kept at Haramaya University Plant Protection Laboratory at room temperature for about a week (Merkuz and Getachew, 2012).

\subsubsection{Extraction of Botanicals}

The fresh leaves, rhizomes and seeds of the selected botanicals were collected and dried under shade. The dried materials of each plant species were ground into powder separately using a sterilized mortar and pestle and they were sieved (Hubert et al., 2015). Crude plant extracts were obtained by infusing $50 \mathrm{~g}$ of each plant material into $100 \mathrm{ml}$ sterilized distilled water to give $50 \% \mathrm{w} / \mathrm{v}$ in a $500 \mathrm{ml}$ conical flask and the mixtures were incubated at $25-28{ }^{\circ} \mathrm{C}$ for 20 hours (Nduagu et al., 2008; Zida et al., 2008). The infusion was filtered separately through sterile double-layered cheesecloth into a sterile $400 \mathrm{ml}$ beaker and the resulting stock solution was collected and stored at Haramaya University Plant Protection Laboratory at $25-28{ }^{\circ} \mathrm{C}$ until used (Mamiro and Royse, 2004).

\subsubsection{Seed Treatment}

The Gubyesorghum variety of inoculated sorghum seeds were treated with the abovementioned seed treatment methods, separately for each, at the rate of $20 \mathrm{ml} / 200 \mathrm{~g}$ seeds for 30 minutes (Aschalew et al.,2012; Samuel et al., 2014). The fermented cow-urine was mixed with the same amount of water (20 ml water $+20 \mathrm{ml}$ fermented cow-urine) for $200 \mathrm{~g}$ seeds for 30 minutes (Girma et al., 2008; Aschalew et al., 2012; Samuel et al., 2014). Only pure water was also used in a similar way as seed treatment method for comparison. In all treatments, the soaked seeds were steered with the spoon, to evenly treat all surface of the seeds. After 30 minutes of soaking, the seeds were filtered and left to dry completely under shade condition. There were also two checks, including Apron star (fungicide) $10 \mathrm{~g} / 4 \mathrm{~kg}$ seed (Samuel et al., 2014), and untreated seed as a standard and control checks, respectively. In the Apron star seed treatment, very little water was dropped on the smut inoculated seeds to facilitate the adhere of the chemical with the seed. Finally, the Apron star was mixed with the inoculated seeds and scratched manually by hand with the help of the gauntlet. These inoculated and treated seeds were sown on 15 July 2016 in well prepared seedbedsat SheraroExperimental Station of Shire-Maitsebri Agricultural Research Center with all recommended and appropriate agronomic practices of the area.

\subsection{Data Collection}

\subsubsection{Phenological Data}

The treated sorghum seeds were sown on 15 July 2016 and the rain started on 18 July 2016. Based on the first date, when the rain started as an initial point, the following phonological data were collected during the experimental period.

Days to emergence: Seedling emergence was recorded by counting the number of days required for seedlings to emerge above the soil surface. That is, the number of days was recorded starting from when the rain was started up to the date when all or almost all of the seedlings in a plot emerged.

Days to 50\% flowering: Days to $50 \%$ flowering were recorded by counting the number of days starting from the date when the rain was started up to the date when $50 \%$ of the plants in a plot flowered.

Days to $90 \%$ physiological maturity: Days to physiological maturity were recorded by counting the number of days starting from the date when the rain was started up to the date when more than $90 \%$ of the plants were physiologically matured. 
Efficacies of Some Botanicals Against Covered Kernel Smut [Sphacelotheca Sorghi (Link) Clinton] of Sorghum [Sorghum Bicolor (L.) Moench] at Sheraro, Northwestern Tigray, Northern Ethiopia

In addition to the above phenological data, the plant height data were also recorded by measuring starting at the base of the plant to the end of the panicle. This was done when the plant terminated its growth or reachedits physiological maturity from both infected and healthy plants together.

\subsubsection{Disease Assessment}

The following disease data (disease incidence and disease severity) were collected during the experimental period. Incidence was scored from all plants in the plot, and severity was scored from 30 plants in a plot using standard procedures.

Disease incidence (I): Proportion of the infected plants was assessed during the onset of the disease. It was recorded by counting the number of plants showing the symptom and dividing by the total number of plants assessed in the three rows per plot; then the results were expressed in percentage of disease incidence using the following formula:

$\mathbf{I}(\boldsymbol{\%})=$ Number of infected plants $\times 100$

Total number of plants assessed

Disease severity (S): Severity was scored at physiological maturity by counting total, healthy and infected number of spikes in each infected head (up to 30 heads) per plot and dividing the number of infected spikes by the number of total spikes in each infected panicle then multiplying by 100 to know the effect of the disease on the proportional percentage of the spikes.

$\mathbf{S}(\%)=$ number of infected spikes in a panicle $\times 100$.

Total number of spikes in a panicle

Where: $\mathbf{S}(\boldsymbol{\%})=$ disease severity in percent

This percentage severity of the diseased plants was changed to scales using modified severity rating scale (1 - 9 rating scale) as used by Samuel et al. (2014), and Teklay and Muruts (2015), as presented hereunder (Table 3).

Table3. Disease severity rating scales for sorghum covered kernel smut using 1-9 at Sheraro Experimental Station during 2016 main cropping season

\begin{tabular}{|c|c|}
\hline Rating scale & Observed severity \\
\hline 1 & No infected florets \\
\hline 2 & $\leq 10 \%$ infected florets \\
\hline 3 & $11-20 \%$ infected florets \\
\hline 4 & $21-29 \%$ infected florets \\
\hline 5 & $30-41 \%$ infected florets \\
\hline 6 & $42-52 \%$ infected florets \\
\hline 7 & $53-63 \%$ infected florets \\
\hline 8 & $64-74 \%$ infected florets \\
\hline 9 & $\geq 75 \%$ infected florets \\
\hline
\end{tabular}

The severity grades were converted into percentage severity index (PSI) for analyses as indicated by Wheeler (1969):

PSI $=\frac{\text { Sum of individual numerical ratings }}{\text { Total number of plants assessed } \mathrm{x} \text { maximum disease score on scale }} \times 100 \ldots$

Yield and Yield Components

The following yield and yield components (thousand grains weight and total yield per plot) data were collected during the experimental activities.

Thousand grains weight $(\mathbf{g})$ : It was measured after the sorghum crop was harvested and threshed by counting one thousand grains and weighing them together for each treatment. The actual moisture content of the grains was measured by using standard moisture tester (grain moisture meter) for each plot. Then the final 1000 grains weight was adjusted to $13.5 \%$ moisture content $(\mathrm{mc})$ (Hellevang, 1995) using the following formula:

Adj.1000 gw $(\mathrm{g})=\underline{(100-\mathrm{AcMc})} \times \mathrm{Ac1000 \textrm {gw } ( \mathrm { g } )}$

$(100-13.5 \% \mathrm{Mc})$

Where: Adj.1000 gw (g) = Adjusted 1000 grains weight in gram

International Journal of Research Studies in Agricultural Sciences (IJRSAS) 
AcMc $=$ Actual moisture content of the grains measured immediately after threshing.

Ac1000 gw $(\mathrm{g})=$ Actual 1000 grains weight in gram measured immediately after threshing.

Actual total grain yield per plot (kg): The yield for each plot also was computed, similar to the thousand grain weight after the sorghum crop was harvested and threshed by weighing the harvested grain of each plot at actual moisture content and then adjusting to $13.5 \%$ moisture content in a similar way but separately for all plots using the following formula.

$\operatorname{AdjGY}(\mathrm{kg})=(100-\operatorname{Ac~Mc}) \times \operatorname{AcGY}(\mathrm{kg})$

$(100-13.5 \% \mathrm{Mc})$

Where: $\operatorname{AdjGY}(\mathrm{kg})=$ Adjusted grain yield weight in kilogram per plot

AcMc $=$ Actual moisture content of the actual grain yield measured immediately after threshing

AcGY $(\mathrm{kg})=$ Actual grain yield weight in kilogram per plot measured immediately after threshing.

After the yield is obtained per plot for each treatment, it was converted to yield per hectare by using the following formula:

Yield per hectare $(\mathrm{kg})=\underline{\text { Actual yield }(\mathrm{kg}) \times 10000 \mathrm{~m}^{2}}$

$$
\text { Actual plot area }\left(\mathrm{m}^{2}\right)
$$

\subsubsection{Relative Yield Loss Assessment}

The highest (potential) yield was obtained on the fungicide (Apron star) treated plots because there was no infected plant as well as loss of yield in the Apron star treated plots. In contrary, the lowest yield was obtained from the control plots, because there was high incidence and severity, and high yield loss percentage in the control plots. Therefore, the Apron star treated and the control plots were used as a reference to calculate yield loss and yield loss reduction percentage.

The relative yield lossPercentage was calculated as follows. First yield difference was calculated for each seed treatment methods by subtracting the yield of plots sown seeds treated with other seed treatment methods from the yield obtained on plots treated with Apron star (standard check fungicide). Then the yield loss percentage was calculated by dividing the yield difference between the yield of Apron star treated plots and other methods to the yield of Apron star treated plots and then multiplying by hundred. Therefore, percentage of yield loss for each treatment was computed using the formula given below as used by Robert and James (1991):

Relative Yield Loss $(\%)=\frac{\text { Ybt }- \text { Ylt }}{\text { Ybt }} \times 100$.

Where: Ybt is the yield of best treatment or maximum protected plot (seeds treated with Apron star) and

Ylt is the yield of lower treatments (seeds treated with other seed treatments).

Loss reduction percentage: The yield loss reduction percentage was worked out to know the amount of loss reduced by using different seed treatment methods. First, the yield loss difference was calculated by subtracting the yield loss percentage scored on other seed treatment methods from yield loss scored on control plots in each replication. Finally, the loss reduction percentage was calculated by dividing the loss difference for each treatment by the yield loss scored on the control plots.

$\mathrm{YLR} \%=\frac{\mathrm{YLC}-\mathrm{YLT}}{\mathrm{YLC}} \times 100$.

Where: YLR\% = yield loss reduction percentage on each treatment

YLC $=$ Yield loss on control plot

YLT $=$ Yield loss on other treatments

\subsection{Data Analysis}

Due to its high CV value, the percent severity index (PSI) data were transformed using arcsine data transformation method as suitable for analysis. Then, statistical analyses for all collected data were performed using GenStat $16^{\text {th }}$ Edition statistical software. The mean separation was done using Duncan's Multiple Range Test (DMRT) at 5\% significant level as described in Gomez and Gomez 
Efficacies of Some Botanicals Against Covered Kernel Smut [Sphacelotheca Sorghi (Link) Clinton] of Sorghum [Sorghum Bicolor (L.) Moench] at Sheraro, Northwestern Tigray, Northern Ethiopia

(1984). The coefficients of correlation and regression analysis were calculated to determine the relationship between yield and disease parameters.

\section{RESULTS AND DISCUSSION}

\subsection{Influence of Different Seed Treatments on Sorghum Crop Phenology and Plant Height}

The analysis of variance (ANOVA) showed that there was a significant $(\mathrm{p} \leq 0.05)$ difference among treatments in days to emergence, days to $50 \%$ flowering and plant height in Gubye variety, but there was no significant difference in days to physiological maturity. Seed treatment with Apron star significantly enhanced field seed emergence (6 days), days to 50\% flowering days (65 days) and plant height $(142.5 \mathrm{~cm})$ (Table 4). Similarly, seed treatment with water (6 days), cow-urine (7 days) and ginger (7.67 days) also significantly enhanced days to field seedling emergence compared to other treatments. However, other treatments showed less influence on days to flowering and plant height than treatment with Apron star, whereas in other treatments field seed emergence was delayed significantly.

Untreated seeds showed similar effect, i.e. as equal as Apron star treatment in days to $50 \%$ flowering but little variation was observed in seeds treated with water. The impact of prolonged seed emergence in stress environments, such as Sheraro, would result inpoor seedling establishment and would affect subsequent plant development. Plots sown with seeds treated with feto, garlic and papaya leaf crude extracts significantly delayed (took 9 days) seedling emergence. This phenomenon could be due to low imbibition of the crude extracts in to the seeds, which consequently leads to delayed emergence of the seedlings. Seeds treated with Eucalyptus leaf crude extract prolonged days to 50\% flowering (took 69.33 days). The control plots also produced the shortest $(125.7 \mathrm{~cm}$ ) plant height (Table 4).

Additionally, Apron star is known to increase crop vigor (Syngenta, 2017); consequently, the vigorous plants due to treatment with Apron star stood first in all aspects as compared to the control and other treatments. The current finding corroborates with the work of Patil et al. (2011) who conducted an experiment on fungicidal management of sorghum covered kernel smut and reported that the seeds sown without fungicidal treatment lead to significantly maximum smut incidence, minimum number of leaves per plant, minimum plant height and minimum ear/head length at maturity as compared with plants produced from the fungicide-treated seeds. The researchers concluded that the minimum plant height is attributed due to high covered kernel smut incidence. Frowd (1980) also explained that infected plants are stunted in height and flowered prematurely.

Table4. Mean values of phenology and plant height of sorghum crop produced from artificially inoculated seeds with Sphacelotheca sorghiand treated seeds with different methods at Sheraro Experimental Station during 2016 main cropping season

\begin{tabular}{|c|c|c|c|c|c|}
\hline S.No. & Treatments & $\begin{array}{c}\text { Days to } \\
\text { emergence }\end{array}$ & $\begin{array}{c}\text { Days to 50\% } \\
\text { flowering }\end{array}$ & $\begin{array}{c}\text { Days to } \\
\text { physiological } \\
\text { maturity }\end{array}$ & $\begin{array}{c}\text { Plant height } \\
(\mathbf{c m})\end{array}$ \\
\hline 1. & Apron star & $6.00 \mathrm{a}$ & $65.00 \mathrm{a}$ & $103.70 \mathrm{a}$ & $142.50 \mathrm{a}$ \\
\hline 2. & Control & $8.00 \mathrm{bc}$ & $66.33 \mathrm{ab}$ & $103.00 \mathrm{a}$ & $125.70 \mathrm{~g}$ \\
\hline 3. & Eucalyptus & $8.33 \mathrm{bc}$ & $69.33 \mathrm{~d}$ & $104.00 \mathrm{a}$ & $132.80 \mathrm{cdef}$ \\
\hline 4. & Feto & $9.00 \mathrm{c}$ & $68.00 \mathrm{bcd}$ & $104.00 \mathrm{a}$ & $129.20 \mathrm{efg}$ \\
\hline 5. & Garlic & $9.00 \mathrm{c}$ & $68.33 \mathrm{~cd}$ & $104.70 \mathrm{a}$ & $133.20 \mathrm{bcde}$ \\
\hline 6. & Ginger & $7.67 \mathrm{abc}$ & $68.33 \mathrm{~cd}$ & $105.30 \mathrm{a}$ & $131.40 \mathrm{def}$ \\
\hline 7. & Neem & $8.67 \mathrm{bc}$ & $69.00 \mathrm{~cd}$ & $104.70 \mathrm{a}$ & $136.50 \mathrm{bc}$ \\
\hline 8. & Papaya & $9.00 \mathrm{c}$ & $68.67 \mathrm{~cd}$ & $104.30 \mathrm{a}$ & $135.30 \mathrm{bcd}$ \\
\hline 9. & Cow urine & $7.00 \mathrm{ab}$ & $68.33 \mathrm{~cd}$ & $104.00 \mathrm{a}$ & $137.60 \mathrm{~b}$ \\
\hline 10. & Water treatment & $6.00 \mathrm{a}$ & $67.33 \mathrm{bc}$ & $104.30 \mathrm{a}$ & $128.30 \mathrm{fg}$ \\
\hline & Mean & $\mathbf{7 . 8 7}$ & $\mathbf{6 7 . 8 7}$ & $\mathbf{1 0 4 . 2 3}$ & $\mathbf{1 3 3 . 2 5}$ \\
\hline & CV $(\boldsymbol{\%})$ & $\mathbf{1 2 . 0 0}$ & $\mathbf{1 . 4 0}$ & $\mathbf{1 . 4 0}$ & $\mathbf{1 . 8 0}$ \\
\hline
\end{tabular}

Mean values within a column followed by the same letter $(s)$ are not significantly different from each other at $5 \%$ probability level of significance using Duncan's Multiple Range Test (DMRT).

Except for the Apron star treated plots, which were vigorous and free of smut, all the other plots that flowered earlier had higher smut incidence and severity than that of the plots that took relativelylonger periodstodays to $50 \%$ flowering (Tables 4 and 5). This phenomenon could happen due to two possible reasons. In the first case, the Apron star could contain plant growth promoter 
compounds. On the other hand, in the second case, the smut-infected plants could reduce their vegetative growth and could enter the reproductive phase earlier because of inability to attain their full growth stage. The latter is in agreement with the observation by Thakur et al.(2007) who reported that the infected-plants tend to boot earlier, and at that time, the teliospores can replace the kernels and are surrounded by a thick membrane (sorus).

Next to plants raised from seeds treated with Apron star, the plants grown from cow-urine, neem and papaya leaf crude extract-treated seeds had taller plant height than plants raised from seeds with other treatments. The increase in plant height due to these treatments might be due to the presence of plant growth enhancing and antifungal factors in the treatments. Kekuda et al. (2014) reported that cowurine and neem leaf extract possessed antifungal properties against many plant pathogenic fungi. Amarnath et al. (2015) also discussed that plant vigor differences due to plant extract and animalurine primed seeds could be attributed to plant growth promotional effect of seed primers, especially bioagents that may produce growth regulatory substances.

\subsection{Effect of Different Seed Treatments on Incidence and Severity of Sorghum Covered Kernel Smut}

The analysis of variance showed that there were significant $(\mathrm{p} \leq 0.05)$ differences among treatments in disease incidence and severity (Table 5). Plants grown from seeds treated with Apron star were completely free from smut infection, while the highest incidence $(30.30 \%)$ and severity $(69.14 \%)$ were recorded in the control plots raised from untreated seeds. The plots sown with seeds treated with fermented cow-urine, papaya and neem leaf crude extracts had incidence of 2.02, 2.36 and 4.04\%, respectively. Similarly, these treatments had severity of 5.93, 6.17 and $9.51 \%$ in that order. In other treatments incidence varied from 6.40 to $18.52 \%$, and severity from 18.15 to $43.83 \%$. This current observation is consistent with the work of Gwary et al. (2007) who reported that the lowest covered kernel smut incidence and severity were recorded on plants raised from Apron star-treated seeds, while the highest covered kernel smut incidence and severity were recorded on the plants from control plots sown with untreated seeds. In other reports, it was also indicated that protective fungicides showed similar effects in controlling smut incidence and seedling blight, and improve crop stand as well as increase crop stability in the absence of soil insects (University of Illinois, 1990).

In addition to the Apron star, the cow-urine, neem and papaya aqueous extracts played a significant role to reduce the incidence and PSI of the covered kernel smut and to enhance the growth and development of the crop, thereby increasing the yield (Tables 4, 5, and 6) as compared with untreated and other treatments. A similar result was reported by Samuel et al. (2014) who evaluated the efficacy of cow-urine and botanical Abyie (Maesalanceolata) against covered kernel smut along the standard check Apron star and control check were found that both treatments controlled the disease as equal as Apron star. The researchers further discussed that these locally available materials could be used as an alternative option to the chemical fungicide Apron star in the management of sorghum covered kernel smut.

Table5. Mean incidence and severity of sorghum covered kernel smut in artificial inoculated and then treated seeds at Sheraro Experimental Station during 2016 main cropping season

\begin{tabular}{|c|c|c|c|}
\hline S.No. & Treatments & Incidence (\%) & Arcsine transformed PSI* \\
\hline 1. & pron star & $0.00 \mathrm{a}$ & $0.00 \mathrm{a}(0.00)$ \\
\hline 2. & Control & $30.30 \mathrm{~g}$ & $56.29 \mathrm{f}(69.14)$ \\
\hline 3. & Eucalyptus globules & $6.73 \mathrm{c}$ & $25.74 \mathrm{~cd}(18.89)$ \\
\hline 4. & Feto & $15.15 \mathrm{e}$ & $41.43 \mathrm{e}(43.83)$ \\
\hline 5. & Garlic & $6.40 \mathrm{c}$ & $25.20 \mathrm{~cd}(18.15)$ \\
\hline 6. & Ginger & $9.43 \mathrm{~d}$ & $31.24 \mathrm{~d}(27.16)$ \\
\hline 7. & Neem & $4.04 \mathrm{~b}$ & $17.74 \mathrm{bc}(9.51)$ \\
\hline 8. & Papaya & $2.36 \mathrm{~b}$ & $14.05 \mathrm{~b}(6.17)$ \\
\hline 9. & Cow urine & $2.02 \mathrm{ab}$ & $13.76 \mathrm{~b}(5.93)$ \\
\hline 10. & Water treatment & $18.52 \mathrm{f}$ & $39.89 \mathrm{e}(42.10)$ \\
\hline \multicolumn{2}{|c|}{ Mean } & $\mathbf{9 . 4 9}$ & $\mathbf{2 6 . 5 3}$ \\
\hline \multicolumn{2}{|c|}{ CV $(\boldsymbol{1 0})$} & $\mathbf{1 8 . 8 0}$ \\
\hline
\end{tabular}

Mean values followed by the same letter (s) within a column are not statistically different from each other at $5 \%$ probability level of significance using Duncan's Multiple Range Test (DMRT).* The values in parentheses are the original values before arcsine transformation. 
Efficacies of Some Botanicals Against Covered Kernel Smut [Sphacelotheca Sorghi (Link) Clinton] of Sorghum [Sorghum Bicolor (L.) Moench] at Sheraro, Northwestern Tigray, Northern Ethiopia

\subsection{Effect of Different Seed Treatment Methods on Grain Yield and Thousand Grain Weight}

The analysis of variance showed that there were significant $(\mathrm{p} \leq 0.05)$ differences among treatments in grain yield, yield loss percentage, yield loss reduction percentage and thousand grain weight (Table 6). On average, $3902 \mathrm{~kg} \mathrm{ha}^{-1}$ grain yield and $35.05 \mathrm{~g}$ thousand grain weight were obtained from plots sown seeds treated with Apron Star®, without any yield loss. Similarly, higher grain yield and insignificant yield loss was recorded in plots sown with seeds treated with aqueous extract of neem, papaya and cow-urine as compared to the control, plots sown with untreated seeds. Cow-urine also showed higher thousand grain weight but as equal as Apron Star ${ }^{\circledR}$ than other treatments, whereas other botanical extracts, though better than the control,gave relatively low yield with higher grain yield loss and relatively less thousand grain weight than the yield and thousand grain weight obtained from other plots sown with treated seeds. In contrast, the lowest grain yield $\left(2005 \mathrm{~kg} \mathrm{ha}^{-1}\right)$, low thousand grain weight $(29.56 \mathrm{~g})$ and high yield loss $(48.56 \%)$ were recorded in the control plots.

This result is in agreement with the observation by Mathad et al. (2013) who reported that seed treatment with babchi (Psoroleacorylifolia L.) showed low infection level and disease severity index. The babchi oil treated sorghum had low infection level and also gave better seed quality parameters, including germination, seedling vigor, improved dry matter and 1000 seed weight. This indicates the presence of certain anti-fungal compounds, which might restrict the growth of Sphacelotheca sorghi and minimize deterioration of the sorghum seed. Similarly, Bdliya et al. (2010) reported that seed treatment with Apron star 42WS supplemented with the foliar application of emulsified neem seed oil significantly reduced the incidence and severity of covered kernel smut and increased both 1000 grain weight and grain yield as compared to the plots sown with untreated seeds. The researchers further suggested that the decrease in disease and increase in yield could be attributed to the reduction in initial infection by covered kernel smut pathogens due to seed treatmentwith Apron star, while at heading three sprays of the neem seed oil on the panicles might have reduced the virulence of the pathogen, and thereby improving grain yield.

The present research result is in agreement with the investigation of Sundaram (1980) who reported that covered kernel smut is the most serious disease if prophylactic control measures are not taken. Samuel et al. (2014) also reported that plants in the control plots were highly affected by the disease and all the florets were changed into smut sori ending with limited normal seeds or low yield.

Based on the current results, the sorghum grain yield loss and yield loss reduction percentages on each treatment were calculated or evaluated in reference with the two checks, i.e. Apron star and untreated control plots. The plots sown with Apron star-treated seeds were superior in all parameters measured; as a result, it was considered as the most effective method because there was no yield loss scored from this treatment. The plots sown with untreated seeds were inferior in all parameters as compared with the other treatments. Similarly, previous researchers reported that covered kernel smut is a severe disease when untreated seeds are sown (Selvaraj, 1980; Sundaram, 1980).

This current finding is in confirmation with the investigation of Patil et al. (2011) who reported that the yield parameters differed significantly in incidence of smut, and the control plots resulted in lower yields and 1000 grain weight than the plots sown with treated seeds, whereas the maximum yields were recorded from plots sown with seeds-treated with vitavax power (carboxin + thiram). Based on their results, the researchers concluded that the increased yield attributes could be due to the vitavax power (carboxin + thiram), which is systemic fungicide in nature that reduced the percentage of smut incidence and enhanced the vigorous development of the crop, whereas the reduction in yield on plots sown with untreated seeds might be attributed to pathogen-induced imbalance in the physiology of host tissue during infection and growth period.

Table6. Mean values of grain yields ( $\left.\mathrm{kg} \mathrm{ha}^{-1}\right)$, yield loss (\%), yield loss reduction (\%) and thousand grain weight $(\mathrm{g})$ in Gobye sorghum variety using different seed treatment methods

\begin{tabular}{|c|c|c|c|c|c|}
\hline S.No. & Treatments & $\begin{array}{c}\text { Grain yield (kg ha' } \\
\mathbf{1} \text { ) }\end{array}$ & $\begin{array}{c}\text { Yield loss (\%) } \\
\text { as compared to } \\
\text { standard check }\end{array}$ & $\begin{array}{c}\text { Yield loss } \\
\text { reduction (\%) } \\
\text { as compared to } \\
\text { control check }\end{array}$ & $\begin{array}{c}\text { Thousand } \\
\text { grain weight } \\
\text { (g) }\end{array}$ \\
\hline 1. & Apron star & $3902 \mathrm{a}$ & $0.00 \mathrm{a}$ & $100.00 \mathrm{a}$ & $35.05 \mathrm{a}$ \\
\hline 2. & Control & $2005 \mathrm{e}$ & $48.56 \mathrm{e}$ & $0.00 \mathrm{f}$ & $29.56 \mathrm{f}$ \\
\hline 3. & Eucalyptus globules & $2877 \mathrm{bc}$ & $26.26 \mathrm{~b}$ & $45.69 \mathrm{c}$ & $32.80 \mathrm{c}$ \\
\hline 4. & Feto & $2414 \mathrm{~cd}$ & $38.12 \mathrm{~cd}$ & $21.49 \mathrm{de}$ & $30.46 \mathrm{e}$ \\
\hline 5. & Garlic & $2998 \mathrm{~b}$ & $23.15 \mathrm{~b}$ & $52.21 \mathrm{c}$ & $32.80 \mathrm{c}$ \\
\hline
\end{tabular}

International Journal of Research Studies in Agricultural Sciences (IJRSAS)

Page | 19 
Efficacies of Some Botanicals Against Covered Kernel Smut [Sphacelotheca Sorghi (Link) Clinton] of Sorghum [Sorghum Bicolor (L.) Moench] at Sheraro, Northwestern Tigray, Northern Ethiopia

\begin{tabular}{|c|c|c|c|c|c|}
\hline 6. & Ginger & $2503 \mathrm{c}$ & $35.83 \mathrm{c}$ & $26.12 \mathrm{~d}$ & $31.96 \mathrm{~d}$ \\
\hline 7. & Neem & $3711 \mathrm{a}$ & $4.75 \mathrm{a}$ & $90.31 \mathrm{ab}$ & $34.13 \mathrm{~b}$ \\
\hline 8. & Papaya & $3705 \mathrm{a}$ & $4.75 \mathrm{a}$ & $85.41 \mathrm{~b}$ & $34.25 \mathrm{~b}$ \\
\hline 9. & Cow-urine & $3784 \mathrm{a}$ & $2.96 \mathrm{a}$ & $93.53 \mathrm{ab}$ & $34.91 \mathrm{a}$ \\
\hline 10. & Water treatment & $2228 \mathrm{dc}$ & $42.88 \mathrm{~d}$ & $11.61 \mathrm{e}$ & $30.39 \mathrm{e}$ \\
\hline \multicolumn{2}{|c|}{ Mean } & $\mathbf{3 0 1 3}$ & $\mathbf{2 2 . 7 5}$ & $\mathbf{5 2 . 6 0}$ & $\mathbf{3 2 . 5 6}$ \\
\hline & CV $(\%)$ & $\mathbf{4 . 0 0}$ & $\mathbf{1 4 . 2 0}$ & $\mathbf{1 1 . 8 0}$ & $\mathbf{1 . 0 0}$ \\
\hline
\end{tabular}

Meanvalues followed by the same letter $(s)$ within a column are not significantly different from each other at $5 \%$ probability level of significanceusing Duncan's Multiple Range Test (DMRT).

\subsection{Association of Disease and Yield Data}

The mean disease incidence values scored across the different seed treatment methods showedhighly significant $(\mathrm{p} \leq 0.01)$ and negative correlation $(\mathrm{r}=-0.88)$ with the yield. Similarly, the mean severity values calculated for the different seed treatment methods showedhighly significant $(\mathrm{p} \leq 0.01)$ and negative correlation $(\mathrm{r}=-0.87)$ with the yield (Table 7). This indicates that those seed treatment methods had different efficacies against the disease. On the contrary, the observed values of the disease also had considerable adverse effects on grain yield of the crop. Generally, the association showed that the two disease measurements (incidence and severity) were inversely related to the amount of grain yield.

The grain yield loss percentage also had highly significant $(\mathrm{p} \leq 0.01)$ and positive correlation with incidence $(\mathrm{r}=0.88)$ and severity $(\mathrm{r}=0.87)$, but it had negative $(\mathrm{r}=-0.99)$ correlation with yield (Table 7). Contrarily, yield loss reduction percentage had a highly significant $(\mathrm{p} \leq 0.01)$ and negative correlation with incidence $(r=-0.88)$ and severity $(r=-0.90)$. Similarly, thousand grains weight also had highly significant $(\mathrm{p} \leq 0.01)$ and negative correlations $(\mathrm{r}=-0.90)$ with incidence and severity $(\mathrm{r}=$ -0.87) (Table 7).

Yield loss reduction percentage and thousand grains weight were highly $(\mathrm{p} \leq 0.01)$ and positively $(\mathrm{r}=$ 0.99 and $\mathrm{r}=0.96$ ), respectively, correlated with yield. These two parameters also had negative correlation $(r=-0.99$ and $r=-0.95)$ in their respective order with yield loss percentage, but each other had positive $(\mathrm{r}=0.96)$ correlation (Table 7$)$.

The correlation coefficients of incidence and severity with both yield and thousand grains weight were negative. This indicates that the reductions in yield and thousand grains weight were aggravated by the covered kernel smut,whereas the seed treatment methods acted against the disease and enhanced the increase in both yield and thousand grain weight. Therefore, a seed treatment method that increases thousand grain weight also increases the yield. This implies that thousand-grains weight and grain yield had direct relationships. Netsanet (2005) reported that a significant effect of the disease on thousand-grain weight could result in a considerable reduction in grain yield of the crop.

Generally, the two disease parameters, i.e., incidence and severity, had negative association with the yield and yield component parameters in all seed treatment methods Table 7).

Table7. Association between yield and sorghum covered kernel smut data on the Gubyesorghum variety at Sheraro Experimental Station during 2016 main cropping season

\begin{tabular}{|c|c|c|c|c|c|c|}
\hline Variables & Incidence & Severity & Yield & Yield loss (\%) & Loss reduction (\%) & TGW (g) \\
\hline Incidence (\%) & 1 & --- & --- & --- & --- & --- \\
\hline Severity (\%) & $0.95^{* *}$ & 1 & --- & --- & --- & -- \\
\hline Yield (kg ha $\left.{ }^{-1}\right)$ & $-0.88^{* *}$ & $-0.87^{* *}$ & 1 & --- & --- & --- \\
\hline Yield loss (\%) & $0.88^{* *}$ & $0.87^{* *}$ & $-0.99^{* *}$ & 1 & --- & --- \\
\hline Loss reduction (\%) & $-0.88^{* *}$ & $-0.87^{* *}$ & $0.99^{* *}$ & $-0.99^{* *}$ & 1 & --- \\
\hline TGW & $-0.90^{* *}$ & $-0.87^{* *}$ & $0.96^{* *}$ & $-0.95^{* *}$ & $0.96^{* *}$ & 1 \\
\hline
\end{tabular}

N.B. $* *$ Correlation is significant at 0.01 level of significant, $T G W=$ Thousand grain weight

Regression analysis also was done for both incidence and severity with yield loss. The coefficient of determination $\left(\mathrm{R}^{2}\right)$ indicated that the incidence accounted for yield loss to the extent of $76.71 \%$, whereas the severity also accounted about $75.9 \%$. Further regression analysis indicates that there was significant linear relationship of yield loss with incidence $(y=1.7372 x+6.4511)$ (Figure 1) and severity $(y=0.7101 x+2.6405)$ (Figure 2$)$. Furthermore, the linear regression coefficients $(b=$ 
Efficacies of Some Botanicals Against Covered Kernel Smut [Sphacelotheca Sorghi (Link) Clinton] of Sorghum [Sorghum Bicolor (L.) Moench] at Sheraro, Northwestern Tigray, Northern Ethiopia

1.7372) in figure 1 indicated that a unit increase of incidence in percent leads to an increase of yield loss by $1.7372 \%$. Similarly, the linear regression coefficient $(b=0.7101)$ in figure 2 also indicated that a unit increase of severity leads to an increase of yield loss by $0.7101 \%$. Based on the basis of correlation regression analysis it is possible to conclude that yield loss can be highly predicted using incidence and severity.

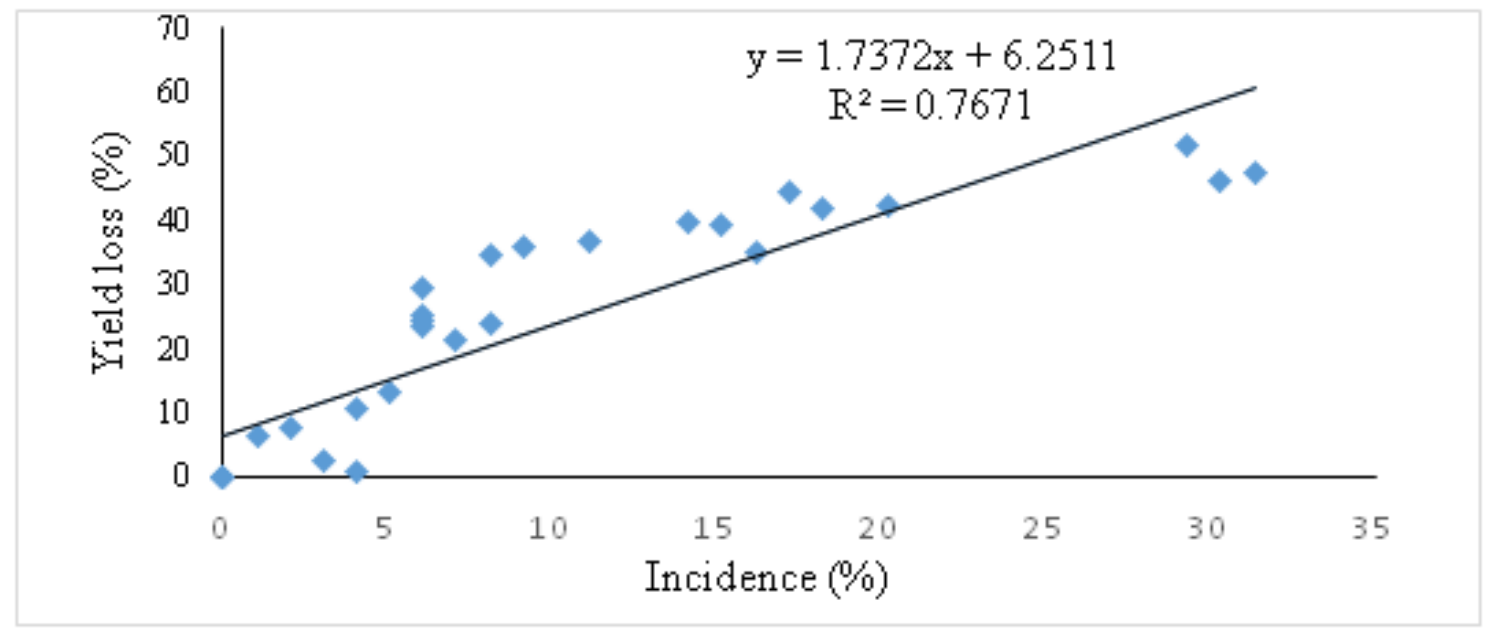

Figure1. Linear regression of yield loss percentage over incidence under different seed treatment methods

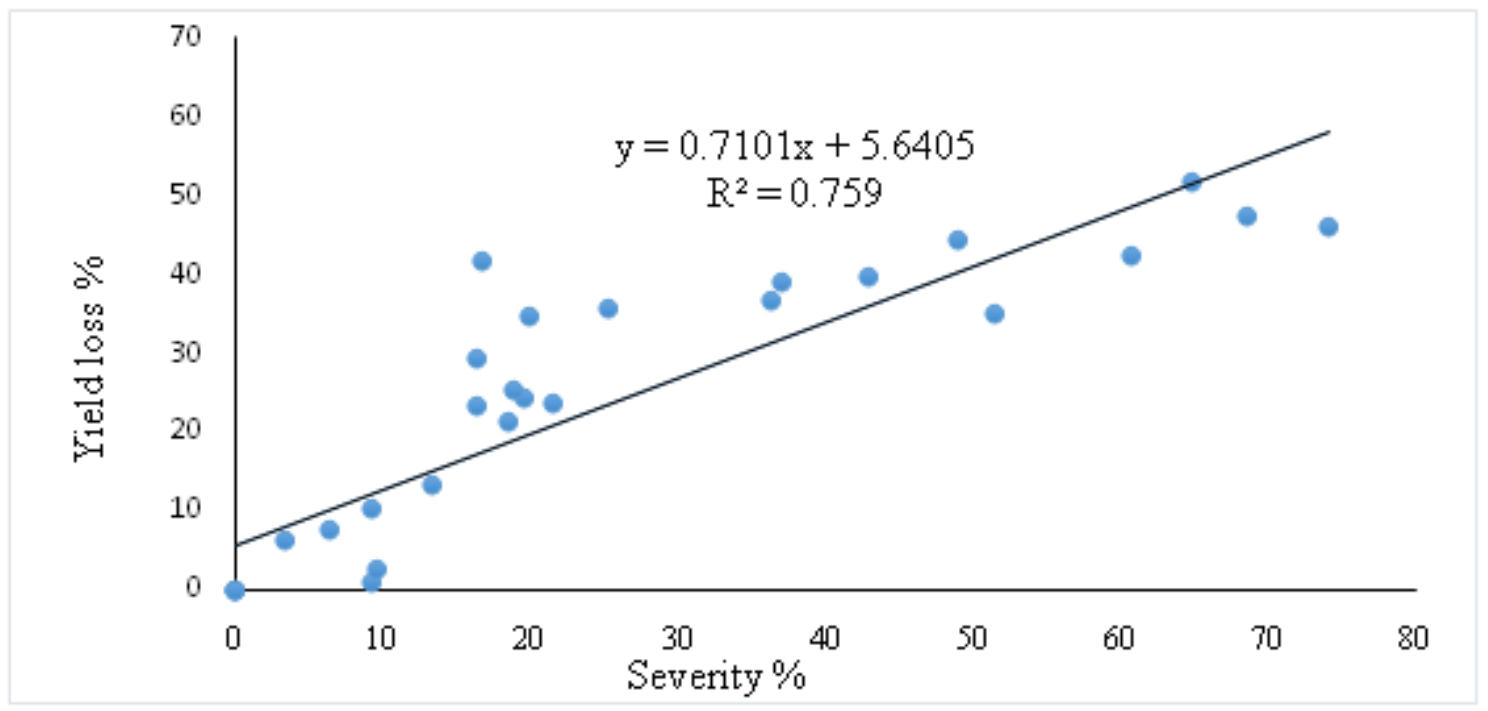

Figure2. Linear regression of yield loss percentage over mean severity under different seed treatment methods

\section{SUMMARY, CONCLUSION AND RECOMMENDATIONS}

The result indicated that the fungicide, botanicals and cow-urine showed a significant difference in controlling smut incidence as compared to the plants grown from untreated control seeds. Plants/plots raised form sorghum seeds treated with Apron star were completely free from covered kernel smut incidence and produced significantly higher $\left(3902 \mathrm{~kg} \mathrm{ha}^{-1}\right)$ grain yield compared to the untreated seeds, which showed the highest(30.30\%) incidence, severity $(51.60 \%)$ and $48.56 \%$ yield loss. Furthermore, Apron star ${ }^{\circledR}$ seed treatment showed an effect enhancing seed germination and promoted better crop stand than the plants raised from untreated seeds. The increased plant height is essentially important for animal feed and fuel for the resource-poor farmers.

Next to the Apron star, seeds treated with cow-urine suppressed smut incidence (2.02\%) and severity $(5.93 \%)$ and resulted in high $\left(3784 \mathrm{~kg} \mathrm{ha}^{-1}\right)$ grain yield. This effect is consistent in many studies in Ethiopia but it is not used widely to bring effective results in managing sorghum covered kernel smut and increasing sorghum production and productivity. Almost similar to that of animal urine, papaya leaf extract also reduced covered kernel smut incidence $(2.37 \%)$, severity $(6.17 \%)$ and offered high $\left(3705 \mathrm{~kg} \mathrm{ha}^{-1}\right)$. Grain yield. Relatively low covered kernel smut incidence (4.04\%) and severity $(9.51 \%)$ as well as higher (3711 $\mathrm{kg} \mathrm{ha}^{-1}$ )yieldwere also obtained from plots sown with seeds treated 
with neem leaf crude extract. In economic terms, the highest net benefit was obtained from plots sown with Apron star-treated seeds, while the highest marginal rate of return also was obtained from plots sown with seeds treated with cow-urine, neem and papaya leaf crude extracts. Therefore, use of Apron star, cow-urine, neem and papaya leaf crude extracts as seed treatments against Sphacelotheca sorghiare economically feasible and can give sustainable production and productivity.

Generally, the Apron star avoids the risk of covered kernel smut infection, and the fermented cowurine and the effective botanicals (neem and papaya leaf crude extracts) will also substitute the expensive fungicides and can avoid extra production costs as well as increase amount of farm return. In addition, these seed treatment materials/botanicals also use as sources or raw materials to produce environmentally safe fungicidal chemicals. Therefore, farmers of Sheraroand other locations with similar agro-ecologies can use the most effective (Apron star) or the effective, environmentally safe and economically feasible seed treatments, such as fermented cow-urine and botanicals (neem and papaya leaf crude extracts).

\section{ACKNOWLEDGEMENT}

This piece of work is a part of an MSc Thesis research done at Haramaya University, and the University deserves gratitude for all its support during the study. We also extend our sincere thanks to the Tigray Agricultural Research Institute (TARI) and Shire-Maitsebri Agricultural Research Center (S-MARC) for financing the research work and providing all the necessary support during the research work.

\section{REFERENCES}

[1] AATF (African Agricultural Technology Foundation) (2011). Feasibility Study on Striga Control in Sorghum. Nairobi, African Agricultural Technology Foundation. 62 pp.

[2] Amarnath BH, Chaurasia AK, Kumar A, Chaurasia N, Vivekanad V, Singh AK (2015). Effect of priming with botanicals and animal waste on germination and seedling vigor in sorghum (Sorghum bicolor L.) seeds. Advanc. Applied Sci.Resear. 6(10): 73-77.

[3] AschalewS, FekedeA, Kedir W (2012). Evaluation of three potential botanicals against sorghum covered kernel smut (Sphacelothecasorghi) at Bako, Western Oromia, Ethiopia. Afr. J. Plant Sci. 6(8): 226-231.

[4] Bdliya BS, KoloAK, Anaso AB (2010). Efficacy of integrating seed treatment with Apron star 42 WS and foliar application of emulsified neem (Azadirachtaindica, A. Juss) seed oil on the management of covered and long smuts of sorghum (Sorghum bicolor L. Moench) in the Sudan Savanna of Nigeria.Archiv.Phytopathol. and Plant Prot. 43(3): 225-232.

[5] Dissanayake M, Jayasinghe J (2013). Antifungal activity of selected medicinal plant extracts against plant pathogenic fungi; Rhizoctoniasolani, Colletotrichummusea and Fusariumoxysporum. Int. J. Science Invent. Today, 2(5): 421-431.

[6] Frowd JA (1980). A world review of sorghum smuts, pp. 331-338. In: Sorghum diseases, a world review: Proceedings of the International Workshop on Sorghum Diseases, 11-15 December 1978, ICRISAT, Hyderabad, India. Patancheru, Andhra Pradesh 502 324, India: International Crops Research Institute for the Semi-Arid Tropics (ICRISAT).

[7] Girma T, Pretorius JC, Swart WJ (2007). Antifungal properties of Agapanthus africanus L. Extracts against plant pathogens. Crop Prot. 27: 1052-1060.

[8] Girma T, Fekede A, Temam H, Tewabech T, Eshetu B, Melkamu A, GirmaD,Kiros M (2008). Review of Maize, Sorghum and Millet Pathology Research. In: Abraham Tadesse (ed.), Increasing Crop Production through Improved Plant Protection - Volume I. Plant Protection Society of Ethiopia (PPSE), 19-22 December 2006. Addis Ababa, Ethiopia. PPSE and EIAR, Addis Ababa, Ethiopia. 598 pp.

[9] Gomez AK, Gomez AA (1984). Statistical Procedure for Agricultural Research, $2^{\text {nd }}$ Edition. Wiley International Science Publication. New York. 680 pp.

[10] Gwary DM, Ali O,Gwary SD (2007). Management of Sorghum Smuts and Anthracnose Using Cultivar Selection and Seed Dressing Fungicides in Maiduguri, Nigeria. Int. J. Agri. Biol.9(2): 324-328.

[11] HassanSA, Mohammed MI,Yagoub SO (2015). Breeding for Dual Purpose Attributes in Sorghum: Effect of Harvest Option and Genotype on Fodder and Grain. J. Plant Breed. Crop Sci.7(4): 101-106.

[12] Hellevang KJ (1995). Grain Moisture Content Effects and Management. Agricultural Extension Service, AE-905 (revised). 8pp.

[13] Hubert J,Mabagala RB,Mamiro DP (2015). Efficacy of Selected Plant Extracts against Pyriculariagrisea, Causal Agent of Rice Blast Disease. Amer. J. Plant Sci. 6: 602-611. 
Efficacies of Some Botanicals Against Covered Kernel Smut [Sphacelotheca Sorghi (Link) Clinton] of Sorghum [Sorghum Bicolor (L.) Moench] at Sheraro, Northwestern Tigray, Northern Ethiopia

[14] Kekuda TRP, Vivek MN, Manasa M, KambarY, Nawaz ASN, Raghavendra HL (2014). Antifungal effect of cow urine extracts of selected plants against Colletotrichumcapsiciisolated from anthracnose of chilli. Int. J. Agri. Crop Sci. 7 (3): 142-146.

[15] Komlaga GA, Johnson PNT,Atokpele DK (2001). Physico-chemical Properties of Four Ghanaian Sorghum (Sorghum bicolor) Varieties: A project report submitted under the IFAD/FRI/ICRISAT Sorghum Improvement Project.

[16] Mathad RC, Shakuntala NM, Vasudevan SN, Naik MN,Patil SB (2013). The anti-fungal properties of aqueous extracts from PsoroleacorylifolialinnSeeds in controlling grain smut and seed quality enhancement of sorghum. Int. Quarterly J. Life Sci. 8(2): 685-687.

[17] Mamiro DP, Royse DJ (2004). Laboratory Efficacy of Selected Fungicides and Rhododendron catawbiense Leaf Extracts on the Growth of Vericilliumfungicola. Acta Edulis Fungi, 12: 390-396.

[18] MerkuzAbera and GetachewAlemayehu. 2012. Evaluation of improved and local (landrace) sorghum varieties for covered kernel smut.Archiv. Phytopathol. Plant Prot. 45(6): 717-723.

[19] Misra HP (2014). Role of Botanicals, Biopesticides and Bioagents in Integrated Pest Management. Odisha Review, pp 62-67.

[20] Murt DS, Renard C (2001). Crop Production in Tropical Africa. Sorghum CTA. 78pp.

[21] Netsanet Bacha. 2005. Management of Common Leaf Rust (PucciniasorghiSchw.) of Maize in Eastern Ethiopia. M.Sc Thesis, Alemaya University, Alemaya Ethiopia.

[22] Nduagu C, Ekefan EJ, Nwankiti AO (2008). Effect of Some Crude Plant Extracts on Growth of Colletotrichum capsici (Synd) Butler and Bisby, Causal Agent of Pepper Anthracnose. J. Applied Biosci. 6(2): 184-190.

[23] ObilanaAB (1995). Review of Sorghum and Millet Improvement Programme in Ghana, 15 pp. A report submitted by SARI, C.S.R.I.

[24] Patil BB, Sajjan AS, Patil SB,Gangashetty PI (2011). Effect of grain smut incidence on crop growth, seed yield and quality parameters of Rabi sorghum. Int. J. Forest. Crop Improv. 2(1): 36-39.

[25] Robert GD, James HT (1991). A Biometrical approach. Principles of statistics, $2^{\text {nd }}$ Edition. New York. USA. 633 pp.

[26] Salehan NM, Meon S, Ismail IS (2013). Antifungal activity of Cosmos caudatus extracts against seven economically important plant pathogens. Int. J. Agri. Biol. 15(5): 864-870.

[27] Samuel T,FuadA, Zeleke L (2014). Evaluation of Efficacy of different Disease Management Practices against Sorghum Covered Kernel Smut (Sphacelotheca sorghi) at Fedis and Babile, Eastern Ethiopia. Research and Reviews.J. Agri. Allied Sci. 3(1): 31-34.

[28] Selvaraj JC (1980). Sorghum Smuts Research and Control in Nigeria. pp. 36-39. In: Sorghum diseases, a world review: Proceedings of the International Workshop on Sorghum Diseases, 11-15 December 1978, ICRISAT, Hyderabad, India, Patancheru, Andhra Pradesh 502 324, India: International Crops Research Institute for the Semi-Arid Tropics (ICRISAT).

[29] Sundaram NV (1980). Importance of Sorghum Smuts in African Countries. pp. 36-39. In: Sorghum diseases, a world review: Proceedings of the International Workshop on Sorghum Diseases, 11-15 December 1978, ICRISAT, Hyderabad, India, Patancheru, Andhra Pradesh 502 324, India: International Crops Research Institute for the Semi-Arid Tropics (ICRISAT).

[30] Swami CS, Alane SK (2013). Efficacy of some botanicals against seed borne fungi of green gram (Phaseolus aureusRoxb.). Biosci.Discov. 4(1): 107-110.

[31] Syngenta. 2017. Apron Star 45 WS. https://www.syngenta.co.ke/product/crop-protection/seed-care/apronstar-45-ws, Last updated: 21.02.2017. Accessed on 03 March 2017, 11:16 AM.

[32] Takele Y, Zemach S (2014). Evaluation of sorghum (Sorghum bicolor (L.) Moench) varieties for yield and yield components at Kako, Southern Ethiopia. J. Plant Sci. 2(4): 129-133.

[33] Thakur RP, Reddy BVS, Mathur K (2007). Screening Techniques for Sorghum Diseases. Information Bulletin No. 76. Patancheru 502 324, Andhra Pradesh, India: International Crops Research Institute for the Semi-Arid Tropics. 86pp.

[34] Tigray Meteorological Agency (2016). Mean annual minimum and maximum temperature $\left({ }^{\circ} \mathrm{C}\right)$ and mean annual total rainfall of Tigray region, Sheraro Station from 2007 to 2016.

[35] University of Illinois (1990). Report on Plant Disease: Sorghum Smuts. College of Agriculture, Consumer and Environmental Science, Urbana-Champaign. 4 pp.

[36] Varma J, Dubey NK (1999). Prospective of botanical and microbial products as pesticides of tomorrow. Current Sci. 76(2): 172-179. 
Efficacies of Some Botanicals Against Covered Kernel Smut [Sphacelotheca Sorghi (Link) Clinton] of Sorghum [Sorghum Bicolor (L.) Moench] at Sheraro, Northwestern Tigray, Northern Ethiopia

[37] Wheeler BJ (1969). An Introduction to Plant Diseases. John Wiley and Sons, Ltd.374 pp.

[38] WortsmannCS, Martha M. Mburu C, Letayo E,Girma A, KayukiKC, Chisi M, Mativavarira M, Xerinda S, Ndacyayisenga T (2009). Atlas of Sorghum [Sorghum bicolor (L.) Moench] Production in Eastern and Southern Africa. 63 pp.

[39] Zida EP, Sereme P, Leth V,Sankara P (2008). Effect of Acacia gourmaensis A. Chev and Eclipta alba (L.) Hassk. on Seed, Health, Seedling Vigor and Grain Yield of Sorghum and Pearl Millet. Asi. J. Plant Pathol. 2(1): 40-47.

Citation: Desalegn Yalew, et.al. "Efficacies of Some Botanicals Against Covered Kernel Smut [Sphacelotheca Sorghi(Link) Clinton] of Sorghum [Sorghum Bicolor(L.) Moench] at Sheraro, Northwestern Tigray, Northern Ethiopia” International Journal of Research Studies in Agricultural Sciences (IJRSAS), 2019; 5(4), pp. 11-24, http://dx.doi.org/10.20431/2454-6224.0504002

Copyright: (c) 2019 Authors. This is an open-access article distributed under the terms of the Creative Commons Attribution License, which permits unrestricted use, distribution, and reproduction in any medium, provided the original author and source are credited. 